\title{
TATA KELOLA KEMITRAN CORPORATE SOCIAL RESPONSIBILITY PT SEMEN TONASA DALAM PENYEDIAAN AIR BERSIH DI DESA BIRING ERE TONASA II KABUPATEN PANGKEP
}

\author{
Sri Fajriani ${ }^{1}$, Fatmawati ${ }^{2}$, Abdi $^{3}$ \\ Universitas Muhammadiyah Makassar \\ e-mail: srifajr@gmail.com
}

\begin{abstract}
This research purposed to find out how the partnership management in the provision of clean water at Biring Ere village, Pangkep Regency. This research used qualitative research with the type descriptive research. The number of informants in the study was 7 people. Data analysis used a qualitative research approach. The type of research used phenomenological research. Data collectiontechniques were instruments in the form of observation, interviews with informants. The data were analyzed descriptively. The results of this research showed that the partnership of the first parrty and the second party in suppling clean be seen from the utilization of clean water supply. But, the development had not been as expected due to the lack of proper maintenance that carried out by the community after post-development. But with the existence of partnersship management, it provided benefits for the community in Biring Ere Village, Pangkep Regency.
\end{abstract}

Keyword: Governance, Parnership, Clean Water

\begin{abstract}
Abstrak
Tujuan dilakukannya penelitian ini ialah untuk mengetahui bagaimana tata kelola kemitraan dalam penyediaan air bersih di desa Biring Ere Kabupaten Pangkep. Jenis penelitian yang digunakan adalah penelitian kualitatif dan tipe penelitian deskriptif. Jumlah informan dalam penelitian adalah 7 orang. Analisis data dalam penelitian ini menggunakan pendekatan penelitian kualitatif.Tipe penelitian yang digunakan dalam penelitian ini adalah tipe penelitian fenomenologi.Teknik pengumpulan data dikumpulkan dengan menggunakan instrument berupa observasi, wawancara terhadap informan.Data tersebut dianalisis secara deskriptif. Hasil penelitian ini menunjukkan bahwa kemitraan pihak pertama dan pihak kedua dalam penyediaan air bersih telah menuai hasil yang positif, hal tersebut dapat terlihat dari pemanfaatan penyediaan air bersih. Namun disamping keberhasilan program ini, dalam hal pengembangannya belum sesuai yang diharapkan karena tidak adanya pemeliharaan yang baik yang dilakukan oleh masyarakat terkait setalah pasca pembangunan. Tetapi dengan adanya tata kelola kemitraan ini memberikan manfaat bagi masyarakat di Desa Biring Ere Kabupaten Pangkep.
\end{abstract}

Kata Kunci: Tata Kelola, Kemitraan, Air Bersih

\section{PENDAHULUAN}

Situasi pembangunan saat ini, tanggungjawab perusahaan tidak lagi dihadapkan pada aspek keuntungan secara ekonomisnya saja.Namun peran perusahaan yang menjadi perhatiaan terbesar dalam lingkungan masyarakat telah ditingkatkan dengan adanya kepekaan dan kepeduliaan terhadap lingkungan dan masalah etika.yaitu kondisi keuangan perusahaan menjadi mutu yang direfleksikan, akan tetapi juga harus mengacuh pada aspek sosial dan lingkungannya. Perusahaan tidak pula sematamata hanya mengacu pada kegiatan ekonomi untuk menghasilkan keuntungan demi kelangsngan usahanya, tetapi juga bertanggungjawab terhadap sosial dan lingkungan. 
Dasar pemikirannya adalah menggantungkan semata-mata kesehatan finansial tidak menjamin perusahaan bisa tumbuh berkelanjutan.Peraturan pemerintah No. 47 tahun 2002 tentang tanggungjawab sosial dan lingkungan perseroaan terbatas, dimana tanggung jawab perusahaan adalah melanjutkan komitmen sebagai bisnis untuk bersikap secara ethnic, bermoral dan berkontribusi pada pembangunan ekonomi. Dimana perusahaan juga harus mengintegrasi antara kegiatan sosial dan masalah lingkungan, yang berhubungan dengan operasi bisnis

Dalam penerapan tata kelola, dukungan infrastruktur dan soft struktur juga memiliki peran yang penting dalam rangka memberikan kejelasan fungsi, hak, kewajiban dan tanggung jawab serta kejelasan sistem yang digunakan secara akuntabel untuk meningkatkan keberhasilan usaha dalam upaya meningkatkan nilai perusahan jangka panjang dengan tetap memperhatikankepentingan stakeholder.

Terminologi kerjasama (partnership) atau kemitraan, lazim digunakan untuk menggambarkan sebuah jalinan kerja antara dua atau lebih individu/organisasi untuk memproduksi suatu barang (goods) dalam memberikan suatu pelayanan (kariem, 2003).

Program kemitraan pada dasarnya merupakan wujud tanggung jawab sosial kepada masyarakat.Secara umum, diwujudkan melalui upaya-upaya untuk memberdayakan masyarakat, meningkatkan kesejahtraan sosial dan pertumbuhan ekonomi masyarakat secara berkesinambungan, dengan tetap menjaga dan memelihara kelestarian lingkungan.

Dengan itu diperlukan kerjasama kolaboratif masing-masing pihak diikat oleh adanya satu kepentingan bersama untuk mencari solusi terhadap masalah atau isu tertentu, yang dirasakan oleh para pihak.Kemaun untuk malakukan kerjasama muncul karena adanya keinginan untuk mencari solusi terhadap masalah yang dirasakan bersama oleh suatu organisasi publik dengan mitrannya dari sektor bisnis atau swasta.Keduannya merasa bahwa masalah atau kepentingan tersebut dapat diselesaikan secara lebih mudah apabila mereka secara bersamasama bekerja untuk mencari solusi terhadap masalah kepengtingan bersama tersebut.

Jogiyanto Abdullah (2011) menjelaskan bahwa tata kelola adalah suatu proses yang dilakukan oleh suatu organisasi atau masyarakat untuk mengatasi permasalahanpermasalahan yang terjadi.

Suatu tata kelola adalah sebagiamana mengubah kebiasaan dalam pengambilan keputusan oleh karena itu pengambilan keputusan harus mengacu kepada prinsipprinsip tata kelola. Pada abad ke-19 Woodrow Wilson (2002) mendefinisikan tata kelola sebagai sebuah pemerintah yang benar dan berhasil melaksanakan suatu kebijakan dengan memperhatikan tingkat efesiensi dan dengan mengeluarkan biaya dan tenaga kerja yang paling sedikit, meskipun sudah lama dikembangkan tata kelola mendapat perhatian yang cukup besar dari kalangan pembuat kebijakan.

Menurut Sulistiyani (2004) secara etimologis partnership, berasal dari kata partner.Yaitu "pasangan, jodoh, sekutu, atau kampanyon".Sedangkan Partnership yaitu persekutuan atau perkongsian. sehingga kemitraan adalah suatu bentuk kerjasama antara dua pihak atau lebih yang membentuk suatu ikatan kerjasama atau bisnis, sebuah perusahaan atau gabungan yang dimiliki bersama oleh badan hukum atau swasta, atas dasar kesepakatan dan rasa saling membutuhkan dalam rangka meningkatkan kapasitas bidang tertentu, atau tujuan sehingga dapat memperoleh hasil yang baik.

Kemitraan dikenal dengan istilah gotong royong atau kerjasama dengan berbagai pihak, baik secara kelompok maupun individual, menurut Notoatmodja (2003), kemitraan merupakan kerjasama formal yang dilakukan antara individu, kelompok, organisasi untuk mencapai suatu tugas atau tujuan tertentu.

Adapun menurut Tugimin (2004), kerjasama adalah usaha atau kegiatan yang dilakukan oleh beberapa pihak secara bersama-sama dengan penuh tanggungjawab untuk memperoleh hasil yang lebih baik daripada dikerjakan secara individu.

Kemitraan bertujuan untuk saling menguntungka $\mathrm{n}$ agar mitra usaha dapat memperoleh nilai-nilai baru dalam melakukan usaha sehingga para mitra dapat memperluas wawasan, kreatifitas dan mampu mengambil resiko terhadap perencanaan kerja yang telah direncanakan.

Tujuan terjadinya suatu kemitraan adalah untuk mencapai hasil yang lebih baik, dengan saling memberikan manfaat antara pihak yang bermitra, dan bukan sebaliknya ada suatu 
pihak yang dirugikan atau merugikan. Untuk mendapatkan keseimbangan dan konsistensi antara satu dengan lain, maka para mitra harus menguntungkan serta memperbesar manfaat (Sulistiyani, 2014).

Kemitraan dapat dilakukan oleh beberapa pihak baik perorangan maupun badan hukum atau kelompok.Pihak yang bermitra tersebut memiliki status yang setara dan saling melengkapi dan menutupi masalah masingmasing pihak yang salang bermitra, memiliki kesamaan misi atau visi yang berbeda tetapi saling melengkapi secara fungsional dengan mempertimbangkan masalah yang ada.

Dilihat dari asal katanya, Corporate Social Responsibility (CSR) berasal dari literatur etika bisnis di Amerika Serikat dikenal sebagai corporate social responsibility atau social responsibility of corporation. Kata corporation atau perusahaan telah dipakai dalam bahasa indonesia yang diartikan sebagai perusahaan, khususnya perusahaan besar. Dilihat dari asal kataya, "perusahaan" berasal dari bahasa Latin "cospus/corpora" yang berarti badan. Dalam sejarah perusahaan dijelaskan bahwa perusahaan itu merupakan suatu badan huku yang didirikan untuk melayani kepentingan umum, namun dalam perkembangannya justru menumpuk keuntungan. (Isa dan Buryra 2007).

Menurut Achda (2006), Corporate Social Responsibility (CSR) dapat diartikan sebagai komitmen perusahaan untuk mempertanggungjawabkan dampak operasinya dalam dimensi sosial, ekonomi dan lingkungan, serta terus-menerus menjaga agar dampak tersebut menyumbang manfaat kepada masyarakat dan lingkungan hidupnya. Konsep tanggung jawab sosial perusahaan atau Corporate Social Responsibilty (CSR), muncul sebagai akibat adanya kenyataan bahwa pada dasarnya karakter alami dari setiap perusahaan adalah mancapai keuntungan semaksimal mungkin tanpa memperdulikan kesejahtraan karyawan, masyarakat dan lingkungan alam.

Seiring dengan meningkatnya kesadaran dan kepekaan dari stakeholders perusahaan maka konsep tanggung jawab sosial muncul dan menjadi bagian yang tidak terpisahkan dengan kelangsungan hidup perusahaan di masa yang akan datang. Tanggung jawab sosial perusahaan dapat didefinisikan secara sederhana sebagai suatu konsep yang mewajibkan perusahaan untuk memenuhi dan memperhatika kepentingan para stakeholder dalam kegiatan operasinya mencarai keuntunga.

Selain itu, ISO 26000 mengenai Guidance on Socal Responsibility juga memberikan definisi corporate social responsibility (CRS). Meskipun pedoman corporate social responsibility (CSR) standar internasional ini baru akan ditetapkan tahun 2010, draf pedoman ini bisa dijadikan rujukan.

Menurut ISO 26000, corporate social responsibility (CSR) adalah tanggung jawab sebuah organisasi terhadap dampak-dampak dari keputusan-keputusan dan kegiatankegiatan pada masyarakat dan lingkungan yang diwujudkan dalam bentuk perilaku transparan dan etis yang sejalan dengan pembangunan berkelanjutan dan kesejahtraan masyarakat. Mempertimbangkan harapan pemangku kepentingan, sejalan dengan hukum yang ditetapkan dan norma-norma.

\section{METODE}

Penelitiaan ini menggunakan penedekatan kualitatif artinya data yang dikupulkan bukan berupa angka-angka melainkan data tersebut berasal dari hasil wawancara, catatan lapangan, dokumen pribadi, catatan memo, dana dokumen resmi lainnya. Dengan tipe penelitan deskriptif bertujuan memberikan gambaran umum berbagai macam data yang dikumpulkan dari lapangan secara objektif, Untuk kebutuhan pengumpulan data. Sumber data yaitu data primer berupa data yang diperoleh dari partisipan, yaitu dengan melakukan wawancara terhadap informan. Adapun yang menjadi informan pada penelitian ini adalah Kepala Biro CSR (Corporate Social Responsibility) PT. Semen Tonasa, Kepala Umum Forum Mitra Amanah Desa Biring Ere, Bendahara Forum Mitra Amanah Desa Biring Ere, beserta masyarakat yang mendapaka penyeluran penyediaan air bersih. Data sekunder dalam penelitian ini yaitu data yang dikumpulkan peneliti dari berbagai catatan laporan-laporan atau dokumen-dokumen yang bersifat informasi tertulis yang digunkan dalam penelitian.

Pengumpulan data digunakan oleh peneliti yaitu teknik wawancara, observasi, dan dokumentasi sedangkan dalam teknik analisis data menggunkan reduksi data, sajian data dan penerikan kesimpulan. Serta untuk 
pengabsahan data menggunakan empat triangulasi yaitu triangulasi data, triangulasi pengamat, triangulasi data dan triangulasi metode.

\section{HASIL DAN PEMBAHASAN}

Kabupaten Pangkep (Pangkajene dan Kepulauan) terletak di bagian barat dari Provinsi Sulawesi Selatan, dengan Ibukota Pangkajene sebagai pusat pelayanan wilayah bagi Kabupaten Pangkep (Pangkajene dan Kepulauan) dengan luas wilayah 1.112,29 km² atau $111.229 \mathrm{Ha}$ dan mempunyai ketinggia tempat rata-rata 8 meter diatas permukaan laut. Secara geografis Kabupaten Pangkep (Pangkajene dan Kepulauan) terletak diantara $4^{\circ} 40^{\prime}$ LS sampai $8^{\circ} 00^{\prime} \mathrm{LS}$ diantara $110^{\circ} \mathrm{BT}$ sampai dengan $119^{\circ} 48^{\prime} 67^{\prime}$ BT. Dimana Kabupaten Pangkep (Pangkajene dan Kepulauan) terdiri dari 9 Kecematan terletak pada wilayah daratan dan 4 Kecematan terletak di wilayahKepulauan. Berdasarkan data monografi desa Biringere yang luas wilayahnya $923,767 \mathrm{~km}^{2}$ ini berbatasan dengan Desa Mangilu di sebelah Utara dan Timurnya, dengan Kelurahan Bontoa di sebalah Selatannya, dan dengan Desa Taraweang di sebelah Baratnya. Masyarakat desa Biringere berpenuturan Bugis dan Makassar, terdiri dari empat kampung yanitu Borong Untia, Palattae, Balang dan Biringere.Desa birig ere terletak $11 \mathrm{~km}$ ke arah Timur dari Kecematan Bungoro.Desa yang terdiri dari 2 Dusun dan 1 kompleks perumahan Karyawan PT. Semen Tonasa.Desa Biring Ere mempunyai luas wilayah seluas 923,767 M2 dengan ketinggian atas permukaan laut $100 \mathrm{M}$.

PT. Semen Tonasa adalah produsen semen terbesar di kawasan timur Indonesia yang menempati lahan seluas 715 hektar di desa Biringere, Kecematan Bungoro Kabupaten Pangkep, sekitar $68 \mathrm{~km}$ dari kota Makassar. Perseroan yang memiliki kapasitasterpasang 5.980.000tonsemen pertahun yang mempunyai 4 unit pabrik yaitu, Pabrik Tonasa I, Pabrik II, Pabrik III, Pabrik IV.

Sedangkan Forum Mitra Amanah adalah forum yang dibentuk oleh masyarakat yang ada di Desa Birngere yang berfungsi sebagai penyambung aspirasi masyarakat ke PT. Semen Tonasa terhadap dampak yang ditimbulkan perusahaan.
Profan dan Milward (1994) memperkenalkan tentang pengelolaan pemerintahan baru dengan konsep hollow state, dimana dalam bentuk kemitraan konsep ini pekerjaan pihak pertama lebih banyak digantungkan ke pihak kedua sehingga pihak pertama hanya menangani masalah yang esinsial saja. Pada konsep hollow state, ada tiga hal utama yang menjadi fokus dalam hubungan kemitraan. Mekanisme

Mekanisme dalam hollow state yang membedakan dengan pemerintahan pada umumunya yaitu mekanisme birokrasi, dimana pada konsep ini mempunyai sedikit order/perintah serta mekanisme kontrol. Terdapat banyak potensi fleksibel untuk mengubah yang ada. Mekanisme disini termasuk didalam nya adalah bantuan dana, kesepakatan serta kontrak, dan tidak berdasrakan otoritas dan sanksi dari pihak pertama.

Ketika pihak pertama sanggup menjadi inti agensi dalam mengotrol mekanisme tata kelola kemitraan tersebut dapat dilihat dari prespektif Hollow State bersifat terintegrasi atau tdiak terfragmentasi, dimana efektivitas kerjasama dapat dicapai dengan baik. Sebaliknaya ketiga mekanisme dalam proses tata kelola kemitraan/kerjasama terpisah, dan tidak terlihatnya peren pihak pertama sebagai inti agensi, maka mekanisme dalam proses tersebut terfragmentasi.

\section{Struktur}

Dimensi kedua yang terdapat dalam teori konsep hollow state yaitu fokus pada tipe struktur suatu kemitraan yang dilakukan pihak pertama kepada pihak pihak kedua. Pembahasan struktur dalam konsep hollow state ini bukan merupakan pemahaman kovensional mengenai struktur organisasi/ kerja pada suatu kemitraan, tetapi membahas tentang tugas dan peran aktor-aktor yang nantinya akan terlibat pada kegiatan kerjasama. Tipe struktur dalam konsep hollow state menyatakan bahwa struktur akan berjalan dengan baik ketika jaringan aktor-aktor terintegrasi, dimana ketika integrasi ini tersentralisasi melalui satu inti agensi. Aktor yang terintegrasi yang dimaksud adalah pihak pertama dan pihak kedua yang terlibat didalam kerjasama.Struktur ini memfasilitasi terciptanya suatu koordinasi dan integrasi serta 
relatif lebih efesien.Dalam pembahasan konsep ini, jaringan arus utama terpisahkan dari kelemahan karena kebutuhannya berkoordinasi sehingga kondisi yang tidak stabil. Pihak pertama dan pihak kedua bekerjasama dalam penyelenggaraan pelayanan publik, selain itu pihak pertama tetap menjaga fungsi sistem integrasi dengan bertanggungjawab dalam hal negosiasi, monitoring dan evaluasi kontrak.

Hal-hal yang sifatnya rule oriented bukan menjadi fokus dan tidak telalu ditonjolkan dalam penyelenggaraan pelayanan publik.

\section{Insentif}

Tipe ketiga dalam konsep hollow state yaitu insentif. Definisi insentif berdasarkan perspektif ini yaitu suatu hal yang diberikan oleh pihak pemberi kerja kepada pihak penerima pekerjaan untuk melakukan program kerjasama dalam proses kemitraan agar dapat berlangsung secara efektif.

Efektivitas dalam suatu kemitraan juga sangat di pengaruhi oleh insentif yang terintegrasi. Teori ini menjelaskan bahwa pendanaan yang baik akan menghasilkan kinerja atau performa yang lebih baik dibandingkan sistem pendanaan yang minim. Ketika tingkat kewajaran dari pendanaan dikombinasikan dengan desain kemitraan atau kelembagaan yang sesuai, stabilitas hubungan antar agen juga berpengaruh.Sistem yang stabil, meskipun di desain secara minim atau pendanaan tidak cukup mengizinkan individu atau lembaga yang terdapat didalamnya sanggup memecahkan suatu masalah dan menyetujui pembagian kerja dalam sistem tersebut.

Pelaksanaan mekanisme tata kelola kemitraan PT. Semen Tonasa dan Forum Mitra Amanah dalam penyediaan air bersih di antaranya: a) Pembiayaan yang dimaksud adalah pendanaan yang diberikan oleh suatu pihak kepada pihak lain untuk mendukung pembangunan yang telah direncanakan, baik dilakukan sendiri maupun lembaga. b) Kontrak yang dimaksud adalah kerjasama yang saling menguntungkan dengan menggunakan bentuk kemitraan sharing cost. c) Evaluasi yang dimaksud adalah suatu proses dalam menyediakan informasi untuk mengetahui sejauh mana kegiatan tersebut telah dicapai. Evaluasi mengukur suatu kegiatan/pekerjaan atau hal-hal yang kita lakukan, evaluasi sangat berguna atau bermanfaat untuk mengetahui tingkatan pekerjaan dan penilaian terhadap apa yang telah dikerjakan dalam pengembangan biogas rumah.

Pada awal pelaksanaan program penyediaan air bersih di desa biring ere kabupaten pangkep, pembiayaan sepenuhnya masih ditangggung oleh PT. Semen Tonasa yang kemudian diserahkan pleh pihak kedua yaitu Forum Mitra Amanah yang bertindak sebagai pengelola anggran.Masyarakat pengguna hanya menanggung biaya kerusakan yang terjadai setalah pasca pembangunan penyediaan air bersih sedangkan sedangkan PT. Semen Tonasa memberikan anggrana $\mathrm{Rp}$. 100.000.000untuk biaya pembangunan penyediaan air bersih.

Kontrak kerjasama PT. Semen Tonasa dan Forum Mitra Amanah merupakan kerjasama yang saling menguntungkan.PT. Semen Tonasa melihat masih kurang nya penyediaan air bersih di Desa Biring Ere karena sebagai masyarakat desa biring ere tidak mampu membayar air bersih untuk digunakan dalam kehidupan sehari-hari. Tata kelola kemitraan ini memiliki niat yang sama mewujudkan ketersediaan penyediaan air bersih bagi masyarakat.

Berdasarkan data yang diperoleh dari PT. Semen Tonasa, program penyediaan air bersih merupakan programa tata keloal kemitraan yang berkerja sama dengan Forum Mitra Amanah serta PT. Semen Tonasa melakukan kerjasamaa dengan Forum Mitra Amanah yang ditandai dengan adanya suratperjanjian kerjasama (SPK) pelaksanaan pekerjaan pembangunan sarana air bersih SK Direksi No.69/KPTS/HK.02.-2012 tentang Pengesahan Blue Print TJSL Tonasa (CSR) dan Program Tematik.

Kerjasama ini berlangsung selama 90 hari kelender terhitung dari tanggal masuknya dana termin/tahap pertama di rekening pihak kedua. PT. Semen Tonasa melakukan kerjasama dengan Forum Mitra Amanah yang saling menguntungkan dengan menggunakan bentuk kemitraan sharing cost.Masing-masing pihak terikat satu sama lain dan menimbulkan hak dan kewajiban diantara para pihak yang membuat perjanjian, sedangkan dalam praktiknya bukan hanya orang perorangan saja yang membuat kontrak / perjanjian, tetapi 
seluruh anggota yang bermitra dalam perjanjian itu.

Jangka waktu pelaksanaan pembangunan penyediaan air bersih sampai selesai $100 \%$ ditetapkan selama 90 (sembilan puluh) hari kelender, terhitung dari tanggal masuknya dana termin/tahap pertama di rekening pihak kedua yaitu Forum Mitra Amanah.

Forum Mitra Amanah berkewajiban dan bertanggung jawab penuh terhadap proses pelaksanaan dan hasil pembangunan penyedian air bersih baik kuantitas maupun kualitas dengan tetap mengacu kepada panduan pelaksanaan dan panduan teknis. Dan menjamin bahwa dana yang diberikan pihak pertama hanya akan digunakan untuk keperluan program penyediaan air bersih yang dimaksud.

Forum mitra amanah didampingi konsultan teknis dan LCO berkewajiban menyiapkan, dan berkewajiban memerikasa dan meneliti rincian rangcangan teknis dan rincian anggaran biaya penyedian air bersih disesuaikan dengan ketersediaan dan harga sumber daya bahan, alat dan tenaga ahli di lokasi dan memastikan bahwa seluruh anggaran yang disediakan sesuai dengan surat perjanjian kerjasama yang sudah disepakati bersama.

Biaya pembangunan pada penyediaan air bersih di Desa Biring Ere membutuhkan dana yang besar, besaran dana berkisar Rp 100,000,000.00. apabila ada kerusakan kecil selanjutnya setelah terselesaikannya pembangunan penyedian air bersih maka biayanya dibebakankan oleh masyarakat.

Sebagai penyedia anggaran, PT. Semen Tonasa hanya menanggung biaya-biaya terkait material dan peralatan pembangunan seperti pipa,selang, kerangka bak beserta baknya, katup atau keran, dan pompa air, serta biaya gaji tukang. Biaya yang sifatnya operasional pascakonstruksi ditanggung oleh pengguna/user.

Dengan adanya kemitraan berdasarkan Sharing Cost, PT. Semen Tonasa dan mitra yaitu Forum Mitrah Amanah dan masyarakat mendapatkan masing-masing keuntungan. Keuntungan dari PT. Semen Tonasa yaitu selain visi dan misi yang sama dengan Forum Mitra Amanah dalam meningkatkan kualitas hidup masyarakat terealisasi. Sedangkan keuntungan yang diperoleh dari Forum Mitra Amanah yaitu visi dan misi dalam menciptakan energi alternatif bagi masyarakat terlaksana dengan baik, masyarakat mendapatkan air bersih serta berkontribusi terhadap kesehatan.

Pada tahapan struktur PT. Semen Tonasa dengan Forum Mitra Amanah menggambarkan dengan jelas pemisahan kegiatan pekerjaan antara yang satu dengan yang lainnya dan bagaimana hubungan aktivitas dan fungsi terbatas.Dalam strukturtersebut yang baik harus menjelaskan hubungan dan wewenang pihak pertama dan pihak kedua sehingga ada pertanggungjawaban dalam melakukan suatu pekerjaan.Dengan adanya struktur organisasi maka kita bisa melihat pembagian kerja dan bagaimana fungsi atau kegiatan yang berbeda bisa dikoordinasikan dengan baik. Selain itu, dengan adanya struktur tersebut maka kita bisa mengetahui beberapa spesialisasi dari sebuah pekerjaan, saluran perintah, maupun penyampaian laporan.

PT. Semen Tonasa adalah pihak pertama atau eleman pertama dalam program penyediaan air bersih di desa Biring Ere.Dukungan aktif dari PT. Semen Tonasa merupakan faktor utama pada keberhasilan penyediaan air bersih di Desa Biring ere. Berdasakan data yang diperoleh dari berbagi informan peran PT. Semen Tonasa dalam penyedian air bersih.

\section{Penyedia Anggaran}

Pembangunan program penyedian air bersih membutuhan dana berkisar Rp. 100.000.000,00 tergantung berapa titik yang akan dibanguni penyedian air bersih. PT. Semen Tonasa sebagai penyedia anggran selanjutnya di serahkan oleh Forum Mitra Amanah sebagai pengelola anggaran dan masyarakat sebagai pemelihara. Ketika ada kerusakan setalah pembangunan penyedian air bersih maka Forum Mitra Amanah dan Masyarakat yang mengumpulkan dana untuk memperbaiki kerusakan-kerusakan kecil yang terjadi.

Sebagai penyedia anggran PT. Semen Tonasa hanya sebagai penyadia anggaran, menggung biaya-biaya terkait material dan peralatan pembangunan penyedian air bersih.Biaya yang sifatnya operasional pascakonstruksi ditanggung oleh pengguna/user. 


\section{Penentu Calon Pengguna dan Calon Lokasi}

Pengguna/user adalah masyarakat yang kurang mampu atau masyarakt yang kesulitan mendapakan air bersih yang ditunjuk langsung oleh PT. Semen Tonasa dan Forum Mitra Amanah. Sedangkan calon lokasi adalah lahan yang dimiliki oleh PT. Semen Tonasa sendiri

Forum Mitra Amanah adalah forum yang dibentuk oleh masyarakat desa Biringere melalui musyawarah bersama yang tergabung dari berbagai elemen yang ada di desa biring ere, lembaga sosial yang dibentuk oleh masyarakat yang berfokus pada peningkatan taraf hidup masyarakat di Desa Biring ere.

Dalam program CSR penyediaan air bersih Forum Mitra Amanah hanya sebagai pengelola anggaran yang dimana anggarannya berasal dari PT. Semen Tonasa.Program penyediaan air bersih sendiri di buat oleh masyarakat yang tergabung di dalam Forum, ketika program yang buat sudah terencanakan selanjutnya diteruskan oleh pengawas lapangan yang di tunjuk langsung oleh PT. Semen Tonasa untuk merealisasikan program tersebut.

Masyarakat hanya sebagai pemelihara dalam pogram CSR penyediaan air bersih di Desa Biring ere, jika ada terjadi kerusakan kecil setalah pasca pembangunan, misalnya pipa yang digunakan bocor maka yang menanggung biaya kerusakan adalah masyarakat yang menerima penyediaan air berish.Biaya nya didapatkan dari uang yang dikumpulkan oleh masyarakat itu sendiri yang menerima penyediaan air bersih. Sedangkan apabila terjadi kerusakan besar masyarakat tidak menanggu biaya kerusakan seperti mesin bor penyediaan air bersih rusak, maka menanggu biaya belum jelas, sebab Forum Mitra Amanah harus melakukan pengadaan untuk proses pembaikan.

Pada bagian ini yaitu insentif peneliti menjelaskan tentang hal apa saja yang diberikan PT. Semen Tonasa terhadap Forum Mitra Amanah agar penyediaan air bersih berjalan dengan efektif. Disini PT. Semen Tonasa hanya memberikan bantuan awal berupa anggaran dana yang kesemua meliputi pemabngunan dari awal sampai akhir. Setalah pembangunan selesai PT. Semen Tonasa tidak mempunyai peran aktif lagi atau tidk memberikan biaya tambahan jika terjadi kerusakan pada penyediaaan air bersih tersebut. Disini cuma Masyarakat lah yang kembali berperan aktif untuk menyediakan anggaran yang dikumpulkan dari masyarakat penerima air bersih kemudian di berikan kepada Forum Mitra Amanah sebagai biaya tambahan atau biaya pemelihraan jika ada kerusakan yang terjadi setalah pasca pembangunan.

PT. Semen Tonasa tidak memberikan insentif dalam pembanguan penyediaan air bersih, karena dana yang berikan dari awal semua sudah meliputi hal-hal apa saja yang diperlukan dalam pembangunan penyediaan air bersih. Di sini sebaliknya masyarakat lah yang memberikan biaya tambahan yang di kumpulkan dari masyaraat yang menerima penyediaan air bersih, biaya tersebut digunkan jika ada keruskan yang terjadi setalah pasca pembangunan penyediaan air bersih di Desa Biring Ere Tonasa II Kabupaten Pangkep.

\section{KESIMPULAN}

Berdasarkan rumusan masalah, hasil penelitian dan pembahasan yang diperoleh pada bab sebelumnya maka kesimpulan pada penelitian ini adalah sebagai berikut:

Mekanisme tata kelola kemitraan PT. Semen Tonasa dan Forum Mitra Amanah pada program CSR dalam penyediaan air bersih antara lain: a) pembiayaan yang dimaksud adalah pemberiaan dana yang diberikan oleh pihak pertama ke pihak yang bermitra agar pembangunya penyediaan air bersih dapat berjalan sesuai dengan apa yang telah direncanakan sebelumnya. b) Kontrak yaitu adanya kerjasama antara satu sama lain dengan menggunakan kemitraan sharing cost. c) evaluasi ialah untuk mengetahui sejauh mana kegiatan yang dijalankan berjalan dengan baik. Evaluasi sangat bermanfaat untuk mengetahui seauh mana tingkat pekerjaan terhadap ada yang telah dikerjakan sebelumnya dalam peneydiaan air bersih.

Dalam struktur tata kelola kemitraan CSR PT. Semen Tonasa dan Forum Mitra Amanah di Desa Biringere Tonasa II Kabupaten Pangkep adalah :a) struktur adalah sutau susunan yang dibentuk oleh suatu sekelompok masyarakat. b) aktor yang terlibat dalam kemitraan ialah PT. Semen Tonasa, Forum Mitra Amanah dan masyarakat sebagai pengguna.

Insentif tata kelola kemitraan CSR PT. Semen Tonasa dan Forum Mitra Amanah yaitu 
pemberiaan biaya tambahan yang dapat digunakan apabila terjadi kerusakan kecil setelah pasca pembanguna.

Berdasarkan uraian kesimpulan diatas, maka dari itu penulis merekomendasikan saran-saran mengenai tata kelola kemittraan CSR PT. Semen Tonasa dan Forum Mitra Amananah berserta masyarakat dalam penyediaan air bersih di Desa Biring Ere Tonasa II Kabupaten Pangkep yaitu sebagai berikut:

PT. Semen Tonasa diharapkan akan selalu menjadi inti agensi dalam pelakasanaan program. Dukungan ini paling dibutuhkan oleh masyarakat penerima air bersih. Dukungan PT. Semen Tonasa dalam hal pemberian dana agar program penyediaan air bersih dapat berjalan dengan baik. Dan Forum Mitra Amanah diharapkan tetap berfungsi membantu masyarakat untuk mengelola anggaran yang diberikan oleh PT. Semen Tonasa.

\section{DAFTAR PUSTAKA}

Ahmad, Mas Daniri. 2005. Good Corporate Governance: Konsep Dan Penerapannya Dalam Konteks Indoesia. Ray Indonesia: Jakarta.

Annual. 2017. Laporan tahun 2016 PT. Semen Tonasa.http://sementonasa.co.id $>68$ 685csrtonasa.html. Diakses 09/02/2018.

Bappenas.2007. Laporan Pencapaian Millenium Development Goals Indonesia. UNNES: Jakarta.

Dwiyanto, Agus. 2011. Manajemen Pelayanan Publik: Peduli, Inklusif, Dan Kolaboratif Edisi Kedua. Gadjah Mada University Press: Yogyakarta.

Fitroh. 2009. Penilaian tingkat kemampuan teknologi informasi pada sistem informasi manajemen akademik. Yogyakarta: seminar nasional aplikasi teknologi informasi.

Hafsah, Muhammad Jafar. 2002. Kemitraan Usaha. Pustaka Sinar Harapan: Jakarta.

Jogiyanto. 2011. Sistem Tata Kelola Teknologi Informasi. Andi: Yogyakarta.

Kariem. 2003. Prinsip Kemitraan. Genta Press: Yogyakarta.

Kadir, Nurhayati. 2012. Penerapan Program Kemitraan Dan Bina Lingkungan (PKBL) PT. Semen Tonasa (Studi Tanggung Jawab Sosial Perusahaan Di Desa Biringere Kabupaten Pangkep Sulawesi
Selatan). Universitas Gadjah Mada: Yogyakarta. http://etd.repositoryugm.ac.id. Diakses 26/04/2018

La'orte, 2002.Tata Kelola Sebagai Sebuah Pemerintah Yang Benar. PT Gramedia Pustaka Utama: Jakarta.

Louis E Boone, David L Kurtz. 2002. Pengantar Bisnis. Erlangga: Jakarta.

Menteri Kesehatan Reublik Indonesia Nomor 1405/MENKES/SK/XI/2002 tentang persyaratan kesehatan lingkungan kerja perkantoran dan industry

Sulistiyani, Ambar Teguh. 2004. Kemitraan Dan Model-Model Pemberdayaan. Gaya Media: Yogyakarta.

Sulistiany.(1999). Skripsi. Depok: fakultas psikologi universitas Indonesia.

Sugiyono, 2014.Metode Penelitian Kuantitatif Kualitatif Dan $R \& D$. Alfabeta: Bandung.

Sugiharto. 1987. Dasar-Dasar Pengelolaan Air Limbah. UI-Press: Jakarta.

Rahmatullah.2014 .Kemitraan CSR Antara Pemerintah, Perusahaan, Dan LSM.Samudra Buku: Yogyakarta.

Tugimin. 2004. Kewarganegaraan. CV Grahadi: Surakarta.

Tenri, Yanti. 2004. Kemitraan Pemerintah dan Swasta dalam Pembangunan Bandara Swadaya Sangia Nibandera Kabupaten Kolaka Sulawesi Tenggara.Https://media.neliti.com>public ations.Diakses tanggal 3 Mei 2018, 13:45 Pm.

Undang-undang No. 40 Tahun 2007 tentang perseroaan terbatas.

Profan, Keith G. and Milward H. Briton. 1994. Governing The Hollow State (Jurnal Yanti Tenri. Kemitraan Pemerintah Dan Swasta Dalam Pembangunan Bandara Swadaya Sangia Nibandera Kabupaten Kolaka). Https://media.neliti.com>publications.

Diakses tanggal 3 Mei 2018, 13:41 Pm,. 364/J Part 10 April 2000.

Peraturan Pemerintah No. 47 Tahun 2002 Tentang Tanggung Jawab Sosial Dan Lingkungan Perseroan Terbatas

Wibisiono, Yusuf. 2007. Membedah Konsep Dan Aplikasi CSR. Fascho Publishing: Gresik. 